УДК 911.3:504.03

JEL A120, O120, O018, R380, R580

\author{
LARYSA CHERCHYK \\ Dr. Econ. Sciences, Professor \\ Lesia Ukrainka East European National University \\ 28 Vynnychenko St., Lutsk, 43021 \\ E-mail: larysacherchyk@gmail.com \\ HTTP://ORCID. ORG /0000-0002-3901-216X
}

\title{
FORMATION OF ECOLOGICALLY ORIENTED URBAN AREAS MANAGEMENT SYSTEM
}

Topicality. The imperfection of the management of urban planning systems and urban areas, the lack of consideration of the environmental component, leads to deteriorating conditions and quality of life in cities, which necessitates the further development of theoretical and methodological principles of environmental management of urban areas.

Aim and tasks. Substantiation of the necessity of formation of ecologically oriented urban areas management system.

Research results. The basic problems of functioning of city territories and their management are determined; the necessity of forming a system of ecologically oriented management of urban territories is substantiated; the regulatory-legal and organizational preconditions for improving the management system of urban areas, taking into account the environmental component; the interpretation of the system of ecologically oriented management of urban areas as a set of principles, methods, means, forms and tools for managing the elements of the urban environment and processes that take place in it in order to ensure a high level of quality of the urban environment in general, environmental safety, social attractiveness and economic efficiency in particular; Its subject, object, basic principles, purpose, criteria of efficiency of functioning are specified.

Conclusions. The study found that there is a significant deterioration in the quality of the urban environment, which is largely due to the imperfection of the management of the processes of urban development, management of the city economy, social and economic environment of the territory; a significant part of the problems of the functioning of urban areas is associated with ignoring the ecological component of city management; regulatory-legal and organizational preconditions exist for the formation of ecologically oriented urban land management system; the basis of the formation of a system of ecologically oriented management of urban areas, it is necessary to put ecologicallyoriented principles, methods, tools and tools that will ensure a high level of quality of the urban environment in general, environmental safety, social attractiveness and economic efficiency.

Key words: urbanized area, ecological component of city management, quality of urban area, ecological safety, social attractiveness.

\section{ЛАРИСА ЧЕРЧИК}

д-р екон. наук, проф.

Східноєвропейський національний університет імені Лесі Украӥнки

Вул. Винниченка, 28, м. Луцььк, Украӥна, 43021

E-mail: larysacherchyk@gmail.com

HTTP://ORCID. ORG/0000-0002-3901-216X

\section{ФОРМУВАННЯ СИСТЕМИ ЕКОЛОГООРІЕНТОВАНОГО УПРАВЛІННЯ МІСЬКИМИ ТЕРИТОРІЯМИ}

Проблема. Недосконалість управління містобудівними системами та урбанізованими територіями загалом, недостатне урахування екологічної складової призводять до погіршення умов та якості життя міст, щзо зумовлює необхідність подальшої розробки теоретичних $i$ методологічних засад екологоорієнтованого управління міськими територіями.

Мета та завдання Обгрунтування необхідність формування системи екологорієнтованого управління міськими територіями.

Результати. Визначено основні проблеми функціонування міських територій та управління ними; обтрунтовано необхідність формування системи екологорієнтованого управління міськими територіями; визначено нормативно-правові та організаційні передумови удосконалення системи управління міськими 
територіями з урахуванням екологічної складової; запропоновано трактування системи екологоріснтованого управління міськими територіями як сукупності принципів, методів, засобів, форм та інструментів управління елементами міського середовища та процесами, які в ньому відбуваються з метою забезпечення високого рівня якості міської території загалом, екологічної безпеки, сочіальної привабливості та економічної ефективності зокрема; уточнено його суб'єкт, об'єкт, основоположні принципи, мету, критерії ефективності функиіонування.

Висновки. У прочесі дослідження встановлено: відбувається суттєве погіршення якості середовища міст, що, значною мірою, пов'язано з недосконалістю управління процесами містобудування, управління міським господарством, сочіальним та економічним середовищем території; значна частина проблем функціонування міських територій пов'язана з ігноруванням екологічної складової в управлінні містом; для формування системи екологооріснтованого управління міськими територіями існують нормативноправові та організаційні передумови; в основу формування системи екологоорієнтованого управління міськими територіями необхідно покласти екологоорієнтовані принципи, методи, засоби та інструментів управлінн, які забезпечать високий рівень якості міської території загалом, екологічної безпеки, соціальної привабливості та економічної ефективності.

Ключові слова: урбанізована територія, екологічна складова управління міськими територіями, якість міської території, екологічна безпека, соиіальна привабливість.

Problem statement and its connection with important scientific and practical tasks. At the current stage of humankind's development, reciprocal influences in the system of "society - nature" is especially pronounced: significant changes in the environment are reflected in the quantitative and qualitative parameters of society development, and the increasing scale of its activities cause irreversible total changes on the environment. This testifies that society and nature are single dynamic system, and its components are characterized by interdependence and active feedback. So, there is a tendency of increasing dependence of society on the natural environment due to exhaustion of natural resources, reduction of the Earth's area per capita, reduction of the assimilation potential of the environment, loss of its primary properties as a favorable environment of life, which in turn is due to an increase in anthropogenic impact on nature. The ecological crisis became systematic. First of all, the ecological crisis is a crisis of the existing society adaptation mechanisms to the environment. There is an urgent need to replace the vector of this interaction through the reform of the institutes of governance.

Particularly relevant ecological problems have been acquired in urban areas. Cities are the main centers of economic, demographic, socio-cultural development of the state. They make a significant part of the national gross product, they are donors of local and state budgets, centers for the development and implementation of industrial and humanitarian technologies, and the development of science and culture. Actualization of the problems of managing a modern city as a complex socio-ecological and economic system, is ensuring a high quality of life, necessitates a rethinking of the principles and systems of local selfgovernment, its organizational-legal, material and financial basis, as well as the responsibility of local government bodies and officials [1].

Analysis of recent publications on the problem. The issues of city management in general, and the city economy in particular, were studied by V. Babayev [2], V. Vakulenko [1, 8], L. Valenkevich [3], I. Kaver [4], O. Kononenko [5], V. Kravchenko [6], V. Kuibida [7], Y. Lebedinsky [8], V. Meshcheryakov [9], M. Orlaty [8], M. Pittsik [6], O. Rybak [10], I. Salii [6] etc.

In particular, M. Orlaty and V. Vakulenko are characterized the state and problems of urban management, substantiated the necessity and methodological foundations of a strategic approach to the management of a modern city, and determined its substantial (functional) blocks [1, 8].

V. Meshcheryakov studied the current state and problems of the city-planning system functioning, regulation of urban development activities, analyzed regulatory and substantiation, substantiated the expediency of community participation in the planning and construction of the city's territory [9]. O. Kononenko researched theoretical approaches and experience of formation of ecologically oriented urban development, determined the main ways of environmentalizing cities [5].

Allocation of previously unsolved parts of the general problem. However, despite all the efforts of world science, there are no ready-made models of sustainable development of society. A global plan for the society development is required, and would combine such elements: scope and durability, integrity and comprehensiveness, which implies consensus building on ideological perspectives for the future, the formation of an ecologically oriented worldview, values, fundamental political, economic and ethical principles. So, the creation of a viable society model requires scientific, economic, technological, 
political, legislate and ideological levels of decision, and the imperfection of the urban planning systems and urban areas management methodology in general, the lack of consideration of the environmental component leads to the need to further develop the theoretical and methodological principles of environmental management of urban areas.

Formulation of research objectives (problem statement): to substantiate the necessity of formation of ecologically oriented urban areas management system, to determine its subject, object, fundamental principles, purpose, criteria of functioning efficiency.

An outline of the main results and their justification. The current ecological situation serves as a limiting factor both for the development of society as a whole, and for the development of separate territories. Therefore, there is an urgent need to reform the institutions of territorial administration, the implementation of environmental imperatives in its structure, reorientation of thinking, system of making management decisions, criteria of efficiency in accordance with the principles of eco-efficiency and ecojustice. The first step here is, on the one hand, a clear understanding of the presence of environmental threats by the external environment, on the other - harmful to the environment from activities within the urbanized areas.

Based on the study of the processes in the municipal economy, one can conclude that the transition to ecologically oriented management should be accompanied by effective environmental and social measures aimed at ensuring optimal development and avoiding mismatches of interests that arise among the stakeholders of the city. It can be achieved through the ecologically-oriented restructuring of the interaction and changing finance priorities from the city budget, which involves investing in environment friendly technologies, financing preventive activities to protect the environment in avoiding further degradation, structural changes in the system of nature and resource use of the city, forecasting changes in the quality of the urban environment as a result of changing social, industrial, infrastructure impact. This involves changing existing managerial approaches to new concepts that will ensure balanced and sustainable development of urban areas.

Practically, it's about of the need to transition to the principles of ecologically oriented management with the wide use of territorial management instruments, environmental and public management. The ecological imperative is dominant in this concept, since the evidence of the current ecological crisis poses the demands of the global community to develop global survival strategies.

Summarizing theoretical and practical aspects of territories ecological management, we should mention that it includes the system of state, local, corporate, public and special ecological management. By forming the mission and the concept of the urban areas development, more and more emphasis is placed on the ecological component, which includes the creation and maintenance of green (park) areas, the implementation of non-waste technologies, environmentally friendly production at enterprises, the introduction of modern technologies for energy and heat supply, sanitation and waste utilization.

Ukraine has set itself the goal of integrating into the European Union, which implies fulfillment of certain requirements. In the EU, more than 300 legal acts (conventions, directives, regulations, rules and recommendations) have been formed that determine its environmental policy.

EU environmental legislation ensures: strict control over emissions from motor vehicles, hazardous chemicals in consumer goods, movement of waste, control of hazardous substances and preparations, etc.; control over activities, production processes that affect the environment or human health; protection of the environment. Procedures and procedural rights for assessing the impact of projects and activities on the environment were identified. In particular, in the EU countries the directive "On the assessment of the effects of certain public and private projects on the environment" such an assessment is required for projects that may have a negative impact on the environment. The Integrated Product Policy (IPP) strategy is being implemented, which aims to promote the market for environmentally friendly products.

Accordingly, in Ukraine processes of creation and implementation of integrated quality management systems (DSTU ISO 9001, DSTU ISO 14000, OHSAS 18000), which meet the requirements of international standards, are taking place. Ukraine has a sufficiently developed ecological legislation; appropriate institutions have been established. Provisions on environmental monitoring and environmental forecasting were introduced.

Developed system of:

- the project of environmental impact assessment documentation (EIA) during the new construction, expansion, reconstruction and technical re-equipment of industrial and civilian objects. The purpose of the 
EIA is to determine the appropriateness and feasibility of the planned activities and to substantiate the economic, technical, organizational, sanitary, state-legal and other measures to ensure environmental safety;

- normative and permit ecological documentation - official permissions and positive conclusions of central or local executive authorities, the obligatory registration of which is determined by the current legislation of Ukraine in the course of economic activity or operation of objects with high or medium risk for the environment;

- documentation on results of the enquiries, on the protection of atmospheric air, surface waters, on the management of waste products, which determine the responsibility for violating the current legislation.

However, in the current system of environmental management, attention is focused on the problems of nature conservation in general or the individual natural resources of the territories. Its disadvantage is the use of predominantly administrative methods of management, usually fiscal, inspection and control functions by management bodies. Another drawback, in our opinion, is the inflexibility of this system and the inability to solve the harmonizing issues of the state economic, social and environmental interests, economic entities, and certain members of society within a certain territory. A rigidly centralized management system, formed by a hierarchical principle that has no alternatives, will not encourage the development of a local initiative and autonomy, and will take into account the problems specific to certain urban areas.

The urban areas ecologically-based management system is a set of principles, methods, approaches, forms and tools for managing the elements of the urban environment and processes that take place in order to ensure a high level urban environment quality in general, environmental safety, social attractiveness and economic efficiency in particular

The urban areas ecologically-based management system has fundamental principles, subject, object, content, purpose and goals of functioning, criteria of efficiency.

The system of ecologically oriented management should be based on the principles of production activity ecologization and high requirements for human well-being, the main of which are: adaptability, risk minimization, orderliness and rationality of actions, taking into account limited possibilities, prevention, determination of responsibility, environmental reversibility.

Adaptability principle. It's necessary to provide constant changes to improve the environment of life, adaptation to the constant strengthening of environmental legislation. Adaptability is considered as a basis for conducting effective economic activity, taking into account the total ecological and economic burden on territorial systems.

The risk minimization principle. Any activity is related to one or another degree of probability of negative environmental impact in general and the danger of deterioration of the environment quality. Risk management involves researching the causes, factors and characteristics of one or another risk situation in order to minimize the negative effects. This problem is especially acute today, when short-term benefits are taken as a basis for activities.

The principle of orderliness and rationality of action involves identifying priorities and activities in accordance with the developed and adopted strategy, the system of strategic, tactical and current city development plans.

The principle of limited opportunities involves the need to allocate resources for the implementation of the most important projects and measures for the formation of an eco-friendly, socially attractive and costeffective city.

The preventive principle. At all stages of the management process, it is necessary to monitor the ecological imperative in the activity of all stakeholders in order to prevent the deterioration of the environmental situation and the city environment quality.

The principle of responsibility implies a clear definition of liability as a wrong decision, especially of a corrupt nature, and for poor quality work in the field of urban construction and management.

These principles require revision of the existing ecologically oriented management system.

Firstly, the object of management must have clear physical boundaries, structure, substantive content of its components and connections.

Secondly, resolving this issue is connected with the necessity of forming a unified approach to the definition of the city territory essence, preferably - of urban space, in order to ensure that the use of terms in new legislative acts, registries, regulations, and state standards is consistent.

Thirdly, an important aspect is the formation of a transparent system for strategic city development financing. 
Fourthly, improving the management of these processes by adapting the organizational structures of the City Hall to coordinate the activities of all services involved in urban construction and management.

Based on the author's definition, the objects of ecologically oriented urban areas management are elements of the urban environment and processes that occur in it.

The subjects of the ecologically oriented management of the urban territories are local selfgovernment bodies, public organizations, and city enterprises.

Criterions of effectiveness of ecologically oriented urban territories management are: satisfactory health of today`s and future generations of the city's population; life safety; proper level of ecological, sanitary and hygienic city territory conditions; high level of comfort of living; the possibility of independent material provision of the inhabitants, their self-realization and development.

The aim of ecologically-oriented urban areas management is to ensure a high level of quality of the urban environment in general, environmental safety, social attractiveness and cost-effectiveness.

Author believe that the greatest challenge is the use of situational management aimed at realizing the short- and medium-term goals of the city development, but solving its environmental problems requires the use of strategic environmental management tools, and its classical scheme includes correction to provide justification, adoption and implementation of management decisions regarding achievement of ecologically safe and economically effective strategic development of the city, namely:

1) formation of ecologically-oriented city development concept, which based on directions and boundaries of the analysis of its environment and surroundings are determined, methods of forecasting, strategic alternatives of development are selected;

2) strategic analysis of the environment, including - the socio, ecological and economic situation. Environmental monitoring and auditing are used to obtain the necessary information. At the strategic analysis stage, it is expedient to use the portfolio analysis method, which allows processing large volumes of heterogeneous information, to determine the main indicators for the diagnosis of socio-ecological and economic security, to predict their changes for the future;

3) diagnostics of the urban space quality condition, factors of which are determined by compliance with the standards of ISO 9001, ISO 14000, OHSAS 18000;

4) forecast of changes in the strategic environment of the city;

5) eco-oriented goal-setting;

6) substantiation of the city development strategic set, including environmental strategies;

7) development of environmental policy. Implementation of environmental policy is aimed at ensuring: saving of costs and resources (primarily natural - raw materials, water, energy) by introducing energy saving technologies, using alternative energy sources, environmentally friendly production at the city enterprises, recycling of primary waste; reduction of discharges, emissions of harmful substances into the environment; quality provision (control) of water, air, foodstuffs in accordance with international standards;

8) improvement of image (as an economic unit) by implementing ecologically oriented innovations;

9) strategic planning of the chosen strategy implementation, which is carried out on the basis of the previous stages data, and is to develop a program of action, substantiation of terms, necessary material, financial and other resources;

10) environmental monitoring, audit and control over the implementation of the strategy and environmental policy. When developing implementation of the chosen strategy interventions, it is necessary to establish the conformity of the city management: priorities of the chosen strategy development; between chosen strategy and organizational processes; in the system of "authority-responsibility" when carrying out strategic changes; organizational structure for strategic change; communications, rules and procedures to new conditions of activity;

11) the choice of tools, methods, levers of influence to ensure the implementation of the chosen strategy, programs and projects. It is important that, at the same time, all of them be organically linked with the goals set and stimulate stakeholders to implement them;

12) the effectiveness of the chosen strategy and environmental policy. The control process involves comparing the desirable state with the actual results achieved and the correction if the results significantly differ from the desired.

Consequently, the ecologically oriented urban areas management system should be considered as an effective tool for ensuring environmental safety, human development, improvement of city's population life quality. 
Conclusions and perspectives of further research. The study found:

1) there is a significant deterioration in the quality of the urban environment, which, to a large extent, is associated with imperfect management of urban planning processes, urban management, social and economic environment of the territory

2) a significant part of the urban areas functioning issues associated with ignoring the ecological component of city management;

3) regulatory-legal and organizational preconditions exist for the formation of ecologically oriented urban areas management system;

4) it is necessary to put ecologically-oriented principles, methods, tools and tools that will ensure a high level of quality of the city's territory in general, environmental safety, social attractiveness and economic efficiency into the basis of the formation of ecologically oriented urban areas management system.

In the organizational plan, formation of ecologically oriented city management provides the following: development of ecologically oriented management concept with widespread use of economic mechanisms, state and local regulation; construction of relationships between economic entities, local governments, relevant supervisory structures on the basis of the regulatory instruments complex use that have a stimulating effect on environmentally-oriented activities, ensuring high quality of the city environment; to implement a system of permits, limits, procedures and rules based on the norms of international environment quality standards and quality of life standards; to use modern territorial forms of urban space organization, which is a prospect for further scientific research.

\section{ЛIТЕРАТУРА}

1. Управління сучасним містом: підручник / за ред. В. М. Вакуленка, М. К. Орлатого. - К. : НАДУ, 2008. - 632 с.

2. Бабаєв В. М. Управління міським господарством: теоретичні та прикладні аспекти / В. М. Бабаєв. - Х. : Вид-во ХРІДУ НАДУ «Магістр», 2004. - 204 с

3. Валенкевич Л. П. Обгрунтування оцінки соціо-еколого-економічного розвитку адміністративно-територіальної одиниці [Текст] / Л. П. Валенкевич, О. О. Павленко, Ю. Т. Алібекова // Механізм регулювання економіки. - 2012. - № 3. - С. 16-25.

4. Кавер И. К. Экономические модели и стратегии развития территорий (в контексте муниципальной реформы) / И. К. Кавер // Економічний часопис. - 2005. - XXI. - Вип. 5-6. - С. 29-32.

5. Кононенко О. Екологоорієнтований розвиток міст: теоретичні підходи та досвід формування / О. Кононенко // Вісник Київського національного університету імені Тараса Шевченка. Географія. 2014. - 1(62). - С. $22-25$.

6. Основи муніципального менеджменту : Навч. посіб. / За ред. В. В. Кравченка. - К. : Атіка-Н, 2003. -304 с.

7. Куйбіда В.С., Кавер І.К. Самоврядування територіальної громади : Монографія / В. С. Куйбіда, І. К. Кавер. - Л. : Літопис, 2006. - 108 с.

8. Державне регулювання розвитку соціальної інфраструктури населених пунктів України: Навч. посіб / М. К. Орлатий, Ю. П. Лебединський, В. М. Вакуленко та ін. - К. : Вид-во УАДУ, 2002. $-112 \mathrm{c}$.

9. Мещеряков В. В. Містобудування як складова управління територіальним розвитком міста / В. В. Мещеряков. // Державне управління: удосконалення та розвиток. - 2012. - № 9. - Режим доступу: http://nbuv.gov.ua/UJRN/Duur_2012_9_14.

10. Рибак О. Регулювання розвитку містобудівного комплексу: економіко-правовий аспект / О. Рибак // Ж-л Економіка. - 2012. - № 1 (115). - С. 88-92.

\section{REFERENCES}

1. Vakulenko, V. M., \& Orlatyi, M. K. et al. (2008) Upravlinnia suchasnym mistom [Management of a modern city]. K. : NADU [in Ukrainian]. 
2. Babaiev, V. M. (2004) Upravlinnia miskym hospodarstvom: teoretychni ta prykladni aspekty [Management of Urban Economics: Theoretical and Applied Aspects]. Kh. : NADU «Mahistr» [in Ukrainian].

3. Valenkevych, L. P. Pavlenko, O. O., Alibekova, Yu. T. (2012) Obhruntuvannia otsinky sotsioekoloho-ekonomichnoho rozvytku administratyvno-terytorialnoi odynytsi [Grounds for the assessment of the socio-ecological and economic development of the administrative-territorial unit]. Mekhanizm rehuliuvannia ekonomiky. - Mechanism of regulation of the economy, 3, 16-25 [in Ukrainian].

4. Kaver, Y. K. (2005) Эkonomycheskye modely y stratehyy razvytyia terrytoryi (v kontekste munytsypalnoi reformы) [Economic models and strategies for the development of territories (in the context of municipal reform)]. Ekonomichnyi chasopys - Economic Journal, XXI, 5-6, 29-32 [in Russian].

5. Kononenko, O. (2014) Ekolohooriientovanyi rozvytok mist: teoretychni pidkhody ta dosvid formuvannia [Ecologically oriented urban development: theoretical approaches and experience of formation]. Visnyk Kyivskoho natsionalnoho universytetu imeni Tarasa Shevchenka. Heohrafiia. - Bulletin of the Taras Shevchenko National Taras Shevchenko University. Geography, 1(62), $22-25$ [in Ukrainian].

6. Kravchenko, V. V., \& et al. (2003) Osnovy munitsypalnoho menedzhmentu [Fundamentals of Municipal Management]. K. : Atika-N [in Ukrainian].

7. Kuibida, V.S., Kaver, I.K. (2006) Samovriaduvannia terytorialnoi hromady [Self-government of the territorial community]. L. : Litopys

8. Orlatyi, M. K. Lebedynskyi, Yu. P., \& Vakulenko, V. M. et al. (2002) Derzhavne rehuliuvannia rozvytku sotsialnoi infrastruktury naselenykh punktiv Ukrainy [State regulation of the development of social infrastructure of settlements of Ukraine]. - K. : UADU [in Ukrainian].

9. Meshcheriakov, V. V. (2012) Mistobuduvannia yak skladova upravlinnia terytorialnym rozvytkom mista [Town-planning as a component of management of the territorial development of the city]. Derzhavne upravlinnia: udoskonalennia ta rozvytok - State administration: improvement and development, 9. Retrieved from http://nbuv.gov.ua/UJRN/Duur_2012_9_14 [in Ukrainian].

10. Rybak, O. (2012) Rehuliuvannia rozvytku mistobudivnoho kompleksu: ekonomiko-pravovyi aspekt [Regulating the development of the urban complex: the economic and legal aspect]. EkonomikaEconomics, 1 (115), 88-92 [in Ukrainian]. 